\title{
A comprehensive fracture prevention strategy in older adults : The European Union Geriatric Medicine Society (EUGMS) statement
}

\section{Blain, $\mathrm{H}$.}

2016-06

Blain , H , Masud , T , Dargent-Molina , P , Martin , F C , Rosendahl , E , van der Velde , N , Bousquet, J , Benetos , A, Cooper , C , Kanis , J A, Reginster , J Y, Rizzoli , R, Cortet , B , Barbagallo, M , Dreinhofer, K E, Vellas , B , Maggi , S, Strandberg , T , EUGMS Falls Fracture Interest Grp , Int Assoc Gerontology Geriatri , European Union Med Specialists EUM , Fragility Fracture Network FFN , European Soc Clinical Econ Aspects \& Int Osteoporosis Fdn IOF 2016 , ' A comprehensive fracture prevention strategy in older adults : The European Union Geriatric Medicine Society (EUGMS) statement ' , Journal of nutrition, health \& aging , vol. 20 , no. 6 , pp. 647-652 . https://doi.org/10.1007/s12603-016-0741-y

http://hdl.handle.net/10138/224103

https://doi.org/10.1007/s12603-016-0741-y

publishedVersion

Downloaded from Helda, University of Helsinki institutional repository.

This is an electronic reprint of the original article.

This reprint may differ from the original in pagination and typographic detail.

Please cite the original version. 


\title{
A COMPREHENSIVE FRACTURE PREVENTION STRATEGY IN OLDER ADULTS: THE EUROPEAN UNION GERIATRIC MEDICINE SOCIETY (EUGMS) STATEMENT
}

\author{
H. BLAIN ${ }^{1}$, T. MASUD ${ }^{2}$, P. DARGENT-MOLINA ${ }^{3}$, F.C. MARTIN ${ }^{4}$, E. ROSENDAHL ${ }^{5}$, N. VAN DER \\ VELDE $^{6}$, J. BOUSQUET ${ }^{7}$, A. BENETOS ${ }^{8}$, C. COOPER ${ }^{9}$, J.A. KANIS ${ }^{10}$, J.Y. REGINSTER ${ }^{11}$, \\ R. RIZZOLI ${ }^{12}$, B. CORTET ${ }^{13}$, M. BARBAGALLO ${ }^{14}$, K.E. DREINHÖFER ${ }^{18}$, B. VELLAS ${ }^{15}$, S. MAGGI $^{16}$, \\ T. STRANDBERG ${ }^{17}$, FOR THE EUGMS FALLS AND FRACTURE INTEREST GROUP, \\ THE INTERNATIONAL ASSOCIATION OF GERONTOLOGY AND GERIATRICS \\ FOR THE EUROPEAN REGION (IAGG-ER), THE EUROPEAN UNION OF MEDICAL SPECIALISTS \\ (EUMS)*, THE FRAGILITY FRACTURE NETWORK (FFN), THE EUROPEAN SOCIETY \\ FOR CLINICAL AND ECONOMIC ASPECTS OF OSTEOPOROSIS AND OSTEOARTHRITIS (ESCEO), \\ AND THE INTERNATIONAL OSTEOPOROSIS FOUNDATION (IOF)**
}

\begin{abstract}
1. Department of Internal Medicine and Geriatrics, Montpellier University hospital; EA 2991 Movement To Health, Euromov, Montpellier University; MacVia-LR, EIP-AHA reference Site; France; 2. Department of Geriatric Medicine, Nottingham University Hospitals NHS Trust Nottingham, United Kingdom; 3. INSERM, U1153, ORCHARD Team, Centre of Research in Epidemiology and Statistics Sorbonne Paris Cité (CRESS), Paris Descartes University, Paris, France; EUGMS; 4. Department of Ageing and Health, Guy's and St Thomas NHS Trust, London, UK; 5. Umeå University, Department of Community Medicine and Rehabilitation, Physiotherapy, Umeå, Sweden; 6. Geriatrics Department Academisch Medisch Centrum Geriatrie, Amsterdam, The Netherlands; 7. Respiratory Diseases Department, Montpellier University hospital; Inserm U1018, Villejuif; MacVia-LR, EIP-AHA reference Site; France; 8. Department of Geriatrics, University Hospital of Nancy, Inserm, U1116, CIC-P 1433, Université de Lorraine, France; 9. MRC Lifecourse Epidemiology Unit, University of Southampton, UK; NIHR Musculoskeletal Biomedical Research Unit, University of Oxford, Oxford, UK, ESCEO/IOF; 10. WHO Collaborative Centre for Metabolic Bone Diseases, University of Sheffield Medical School, Beech Hill Road, Sheffield S10 2RX, UK; 11. Department of Public Health, Epidemiology and Health Economics, University of Liege, CHU Sart Tilman B23, 4000 Liège, Belgium; 12. Service of Bone Diseases, Geneva University Hospitals and Faculty of Medicine, Geneva, Switzerland; 13. Hôpital Roger Salengro, Lille France; 14. Geriatric Unit, University of Palermo, Italy; 15. Gérontopôle, Institute of Ageing, University Hospital Toulouse, France; 16. National Research Council, Aging Branch, Institute of Neuroscience, Padova, Italy; 17. University of Helsinki, and Helsinki University Central Hospital, Helsinki; University of Oulu, Center for Life Course Health Research, Oulu, Finland; 18. Dept. for muskuloskeletal Rehabilitation, Prevention and Health Service Research Center for Sport Science and Sport Medicine (CSSB) Center for Musculoskeletal Sugery (CMSC) Charité, Universitätsmedizin Berlin; Dept. of Orthopedics and Traumatology Medical Park Berlin, Germany ; Fragility Fracture Network, Germany. Corresponding author: H. Blain, Pôle de Gériatrie, Centre Antonin-Balmes, CHU de Montpellier, 39, avenue Charles-Flahault, 34395 Montpellier Cedex 5, France.Tel: +33 467339957. E-mail address: h-blain@chu-montpellier.fr
\end{abstract}

\begin{abstract}
Prevention of fragility fractures in older people has become a public health priority, although the most appropriate and cost-effective strategy remains unclear. In the present statement, the Interest Group on Falls and Fracture Prevention of the European Union Geriatric Medicine Society (EUGMS), in collaboration with the International Association of Gerontology and Geriatrics for the European Region (IAGG-ER), the European Union of Medical Specialists (EUMS), the International Osteoporosis Foundation - European Society for Clinical and Economic Aspects of Osteoporosis and Osteoarthritis, outlines its views on the main points in the current debate in relation to the primary and secondary prevention of falls, the diagnosis and treatment of bone fragility, and the place of combined falls and fracture liaison services for fracture prevention in older people.
\end{abstract}

Key words: Falls, fragility fracture, older people, prevention, position statement.

\section{Introduction}

Three quarters of all vertebral and non-vertebral fractures occur among adults aged 65 years or older and over three quarters of hip fractures occur in people aged 75 or over (1). The major influence of ageing on fracture risk is mainly due to the strong impact of age and age-related conditions on bone strength and fall risk $(2,3)$. Although fractures of the hip are the most serious and costly fractures, those at the spine, pelvis, distal femur, proximal tibia, proximal humerus, and ribs are also major fractures, associated with excess morbidity and mortality, increased hip fracture risk, decreased quality of life, and high health care costs (4-8). With the global growth of the older population, prevention of fractures has become an international public health priority $(4,9,10)$. The most appropriate and cost-effective strategy to prevent major fractures in older people however remains a hotly debated topic (11-14). In the present statement, the Interest Group on Falls and Fracture Prevention of the European Union Geriatric Medicine Society (EUGMS), in collaboration with the International Association of Gerontology and Geriatrics for the European Region (IAGG-ER), the European Union of Medical Specialists (EUMS), the International Osteoporosis Foundation - European Society for Clinical and Economic Aspects of Osteoporosis and Osteoarthritis, outlines its views on the main points in the current debate.

\section{Primary and secondary prevention related to falls}

In adults, falls occur predominantly in older people. In populations over age 65 , a third of community-dwelling people fall at least once per year and in those aged 80 years or more a 


\section{A COMPREHENSIVE FRACTURE PREVENTION STRATEGY IN OLDER ADULTS}

half fall over the course of a year $(15,16)$. More than $80 \%$ of non-vertebral fractures result from a fall $(2,3)$. Around $10 \%$ of falls result in a fracture $(17,18)$ and $2 \%$ in a hip fracture (19). The efficacy of falls prevention interventions to reduce fractures is debated $(13,14)$, in part because it depends on the fall risk profile of people and the type of intervention program $(20,21)$.

There is no international consensus for assessing the fall risk profile of older people, even if it is well understood that people at higher risk of future falls are those aged 75 or older, those who have fallen during the previous 12 months or those who have fear of falling or significant gait, muscle strength, or balance problems $(16,22-28)$. The fall risk profile is also dependent on the setting and some other factors, including cognitive impairment which may be associated with increased risk-taking. Even though balance, gait, and muscle function decline increases the risk of falling, the relationship is not completely linear since those with most problems (i.e. bedridden) usually have a lower falls risk, similar to those without such problems, presumably due to low exposure to risk (29).

Notwithstanding the lack of consensus in assessing fall risk profile, there is rather consistent evidence in subjects with low to moderate falls risk, usually community dwelling, that multicomponent exercise programs, including progressive, challenging and regular exercises designed to improve balance, muscle strength, and protective responses in case of destabilisation, are effective in the reduction of serious falls and non-vertebral fractures $(21,24,30,31)$. The studies are however insufficiently powered to demonstrate a significant effect on hip fracture risk $(21,24,30)$. Single interventions including treatment of some vision problems or carotid sinus hypersensitivity, vitamin D supplementation in deficient patients, gradual withdrawal of psychotropic medication, or improving the safety of indoor activities and outdoor walking environments are also effective for suitable patient groups in the prevention of falls, but the effect on fracture risk is not clear $(21,32,33)$. Multifactorial interventions, a combination of interventions linked to the individual's risk profile, seem no more effective in preventing falls than single targeted interventions (e.g. community exercise or fall prevention programs) $(21,34)$.

In people at high risk of falls single targeted interventions seem less effective, e.g. in older nursing home residents, the only single intervention that has reduced falls is vitamin D supplementation (20). Other interventions have been ineffective or inconsistent for falls although the rate of recurrent falls may be reduced (35). A multifactorial and interprofessional approach, determined by individual assessment of functional, medical, and social concerns, may be a more appropriate strategy to prevent falls in older people at high risk of falling $(20,22-34,36)$. Moreover, this tailored approach (37) may provide opportunities to address previously unidentified health problems (e.g. impaired cognition, diabetes, Parkinson's disease, osteoporosis) $(9,38)$, conferring benefits beyond falls prevention $(39,40)$. People at high risk of fall are most often frail patients (40) and multifactorial approach in this population has been shown to improve the ability to live safely and independently (41).

Taken together, the EUGMS supports 1) the set-up of a working group that would develop consensus international operational definitions and diagnostic criteria for assessing the risk of falling to be used in clinical practice as well as in research studies, 2) the 2010 American Geriatrics Society / British Geriatrics Society joint guideline urging practitioners to screen, at least annually, older patients for risk of falling (42), 3 ) that above evidenced-based measures, especially evidencebased community exercise fall prevention programs, should be widely available to prevent non-vertebral fractures in older people at low or moderate risk of falling (9), and 4) that people at high risk should be able to access individually tailored multifactorial measures based on a comprehensive geriatric assessment. EUGMS recommends continued and expanded provision of evidence based fall prevention programmes such as those being promoted by ProFouND (www.profound.eu.org).

\section{Primary and secondary prevention related to bone health}

It is widely recognized that lifestyle measures (regular weight-bearing exercises, balanced diet, including calcium intake, avoiding smoking and excessive alcohol consumption) and measures aimed at reducing adverse effects on bone of drugs and diseases, including renal diseases, have to be recommended throughout life in everyone. They are beneficial in optimizing skeletal development (43-46) and limiting bone loss during adulthood (47).

Whereas there are well established definitions of osteoporosis $(13,14)$, there is much current debate on what is the target population that may potentially benefit from treatments acting on bone metabolism (TABM) $(13,14,48-51)$.

Osteoporosis is currently defined by bone densitometry (densitometry osteoporosis) when the bone mineral density (BMD) is $2.5 \mathrm{SD}$ or more below that of the mean level for a young-adult reference population (T-score $\leq-2.5$ at the lumbar spine or the hip, or at the distal radius when the hip and lumbar spine cannot be measured or are unusable or uninterpretable) (52-54). Aortic calcification and osteoarthrosis that increase progressively with age may be a source of accuracy error in the measurement of lumbar spine BMD in older people $(55,56)$. However, for a given BMD, the risk of major fractures depends on other risk factors for bone fragility, of which age is the most important one, which are taken into account in different fracture prediction tools such as the most used FRAX® tool (www.shef.ac.uk.FRAX) or the Garvan Fracture Risk calculator (www.garvan.org.au/bone-fracture) or the Q-fracture Risk Calculator (www.qfracture.org). Fragility fracture risk should therefore take into account not only BMD but also other risk factors of bone fragility, by using fracture prediction tools, and falls risk (57). Since falls and osteoporosis are independent risk factors of non-vertebral fractures, osteoporosis should 


\section{JNHA: GERIATRIC SCIENCE}

be ascertained not only in patients with conditions known to induce bone fragility but also in patients at risk of falls and vice versa (58). The prevalence of osteoporosis detected by DXA BMD measurement is high in fallers with sarcopenia, impaired mobility, and weight loss, which are risk factors for both falls and osteoporosis (58).

A fracture is considered a fragility or low energy fracture when it is the result of a minimal trauma, such as a fall from a standing height or less. However, a fall from standing height without any protective response generates an amount of energy which is at least 10 times the energy required to fracture the proximal femur of an elderly woman (59). Diagnosis of fragility fracture should therefore be set after a careful comprehensive assessment including 1) Fracture mechanism consideration (energy of the trauma) and 2) bone strength estimate, based on bone mineral density (BMD), considering that densitometry osteoporosis is observed in around $60 \%$ and $40 \%$ hip fractured women and men, respectively (60), fracture type (comminuted or not, for example) and operator's subjective assessment of bone quality in the case of surgery.

The cost-effectiveness of the pharmacological approach of treating osteoporosis (and therefore on searching for osteoporosis by Dual-Energy X-Ray Absorptiometry (DXA)) is also debated (13). However, several licensed TABM have shown their ability to prevent major fractures in people (most often women) with a T-score $\leq-2.5$ at the spine or the hip (raloxifene has only been shown effective in preventing vertebral fractures) $(14,61)$ or after a hip fracture (61). Relative risk reductions of spine and non-vertebral fractures by TABM in subjects with bone densitometry diagnosed osteoporosis are $40-60 \%$ and $20-40 \%$, respectively $(14,61)$. Number-Needed-toTreat (NNT) to prevent a fracture is lower in people at high risk of fractures, and especially in those with prior fragility fractures $(13,37,61-73)$.

Taken together, EUGMS supports recommendations that 1) osteoporosis should be ascertained by DXA, at best combined with vertebral fracture assessment (VFA) or radiography examination to detect vertebral fractures, in individuals at risk of fracture, i.e. at risk of falling (58) or at risk of bone fragility (history of fracture, low body weight, parental history of hip fracture, use of glucocorticoids, excessive alcohol consumption, diseases with bone adverse effects) (74), 2) TABM should be considered after a careful assessment of the benefit/risk ratio in patients at high risk of fracture, i.e. with a prior fragility fracture or in those with densitometry diagnosed osteoporosis associated with other risks factors of fractures, assessed both by fracture prediction scores and risk of falling 3) TABM should not be initiated when the life expectancy is less than 6-12 months, the minimum time needed for drugs to be effective in fracture prevention (66).

EUGMS recommends that prospective studies be conducted in non-selected older people (particularly in those aged over 80 years) to determine if this strategy is effective, considering that age and health status may modify compliance to treatments and the Number-to-Treat/Number-Needed-to-Harm (NNH) of TABM (61).

\section{Fracture Liaison Services and screening for spine fragility}

As the diagnosis of fragility fracture and the assessment of benefit/risk ratio of the above measures is complex, EUGMS recommends that patients aged 65 years or older with vertebral or non-vertebral fractures should be referred to a fracture liaison service (FLS) (as proposed by the International Osteoporosis Foundation in the Capture the Fracture initiative) (75), which should be linked to or have strong input from geriatric medicine services (combined fall and fracture liaison service). Such an approach will allow commencement of appropriate interventions and ensure locally agreed arrangements for follow-up of patients. This model of care has been shown to be cost-effective $(76,77)$.

EUGMS emphasizes that vertebral compression fractures are common, and often unrecognized in older people. X-ray examination should be more systematically performed in older patients with back pain, significant height loss (e.g. $5 \mathrm{~cm}$ or more), or significant incident kyphosis. Radiologists should be encouraged to report on the presence or absence of vertebral deformities as "fractures" when assessing chest radiographs so as to identify patients who need referral to the combined fall and fracture liaison services (78), as these are mostly fragility fractures in older people (53).

\section{Conclusion}

EUGMS advocates a comprehensive and multidisciplinary fracture prevention strategy in individuals aged 65 or older requiring: 1) Better education for both older people and health care professionals with regards to general lifestyle and medical measures to optimize bone health and prevent falls; 2) Improved knowledge about screening and optimizing management of older people with bone fragility or high risk of falling in primary and community care as well as institutional settings; and 3) Strong collaboration between fracture liaison services, geriatric medicine departments (combined falls and fracture liaison services) and primary care. Policy makers will need to play a major role in developing community and institutional programs on falls prevention, to establish falls and fracture liaison services and appropriate pathways for fracture prevention that include both assessment and management of fallers and optimising medical management in those with bone fragility to reduce fracture risk.

The EUGMS believes strongly that the focus for fracture prevention should not be polarised into either falls prevention or improving bone health camps. Rather the ideal strategy should be on optimising bone health, especially in those with bone fragility, in addition to implementing measures to prevent falls.

This article is being published concurrently by Aging Clinical and Experimental Research, European Geriatric Medicine, and Journal of nutrition, health \& aging". 


\section{A COMPREHENSIVE FRACTURE PREVENTION STRATEGY IN OLDER ADULTS}

Disclosure of interest: The authors declare that they have no conflicts of interest concerning this article.

Ethical standard: Participants provided by e-mail their written consent to participate in this study. Ethics committees/IRBs were not involved in this consent procedure.

*For the EUGMS Falls and Fracture Interest Group: Marta Neira Alvarez, Department of Geriatric Medicine of Infanta, Sofia University Hospital. S S Reyes. Madrid, Spain. (marta.neira@yahoo.es); Cedric Annweiler, Department of Neuroscience, Division of Geriatric Medicine, Angers University Hospital; University Memory Clinic; UPRES EA 4638, University of Angers, UNAM, Angers, France; Robarts Research Institute, Department of Medical Biophysics, Schulich School of Medicine and Dentistry, the University of Western Ontario, London, Ontario, Canada. (CeAnnweiler@ chu-angers.fr); Pierre Louis Bernard, UFR-STAPS, Université Montpellier, EA 2991 EuroMov, Montpellier, France. (pbernard@univ-montp1.fr); Natalie Beswetherick, OBE MBA FCSP, Chartered Society of Physiotherapy, London, UK. (beswetherickn@csp.org. uk); Heike A. Bischoff-Ferrari, Department. of Geriatrics and Aging Research, University Hospital Zurich and University of Zurich, Switzerland; ESCEO/IOF. (Heike.Bischoff@ usz.ch); Frédéric Bloch, Department of Gerontology, Hopital Broca (AP-HP), and University Paris-Descartes, EA 4468, Paris, France. (frederic.bloch@brc.aphp.fr); Jacques Boddaert, Unit of Peri-Operative Geriatric care, Geriatric Department Pitié-Salpêtrière Hospital, CNRS UMR8256 Pierre et Marie Curie University, UPMC Paris 6, France. (jacques.boddaert@psl.aphp.fr); Marc Bonnefoy, Department of Geriatrics, Groupement Hospitalier Sud - HCL Université Claude Bernard, Unité INSERM 1060 69495, PierreBénite Cedex, France. (marc.bonnefoy@chu-lyon.fr); Isabelle Bourdel-Marchasson, Clinical Gerontology Department, CHU Bordeaux, RMSB, UMR 5536, CNRS, Bordeaux University, France. (isabelle.bourdel-marchasson@chu-bordeaux.fr); Ana Capisizu, University of Medicine and Pharmacy «Carol Davila» Geriatric Department - «St Luke» Hospital, Bucharest, Romania. (anacapisizu@yahoo.com); Hélène Che, Département de rhumatologie, Pole Os et articulations, Hopital Lapeyronie Université de Montpellier, Montpellier, France. (h-che@chu-montpellier.fr); João Gorjão Clara, Geriatric University Unit, Instituto de Medicina Preventiva, Faculdade de Medicina da Universidade de Lisboa, Portugal. (gorjaoclara@gmail.com); Bernard Combe, Département de rhumatologie, Pole Os et articulations, Hopital Lapeyronie Université Montpellier I, Montpellier, France; Société Française de Rhumatologie. (b-combe@chu-montpellier.fr); Didier Delignieres, UFR-STAPS, Université Montpellier, EA 2991 EuroMov, Montpellier, France. (didier.delignieres@univ-montp1.fr); Patrik Eklund, Department of Computing Science, Umeå University, SE-90187 Umeå, Sweden. (pe@fourcomp.com); Marielle EmmelotVonk, Department of Geriatrics, University Medical Centre Utrecht, The Netherlands. (M.H.EmmelotVonk@umcutrecht.nl); Ellen Freiberger, Institute for Biomedicine of Aging, Nürnberg, Germany. (ellen.freiberger@fau.de); Jean-Bernard Gauvain, Court Séjour Gériatrique, CHR Orléans, France; GRIO. (jean-bernard.gauvain@chr-orleans.fr); Nandu Goswami, Institute of Physiology, Medical University of Graz, Austria. (nandu. goswami@medunigraz.at); Nick Guldemond, University Medical Centre Utrecht, The Netherlands, (N.A.Guldemond@umcutrecht.nl); Álvaro Casas Herrero, F.E.A Geriatría Complejo Hospitalario Navarra, Pamplona, Spain. (alvaro.casas.herrero@navarra.es); Marie-Eve Joël, Université Paris-Dauphine, Paris, France. (Marie-Eve.Joel@ dauphine. fr); Anna Björg Jónsdóttir, Department of Geriatric Medicine The National.University Hospital of Iceland, Reykjavík -Iceland. (annabjon@landspitali.is); Gilles Kemoun, Laboratoire EA 6314, Université de Poitiers, Institut de Recherche sur le Handicap et le Vieillissement, Paris, France. (gilles.kemoun@wanadoo.fr); Istvan Kiss, Division Section of Geriatrics, 2nd Department of Internal Medicine, Semmelweis University, Budapest, Hungary (ikiss@enternet.hu); Helgi Kolk, Department of Traumatology and Orthopaedics, Tartu University Hospital, Estonia. (Helgi.Kolk@kliinikum.ee); Marek L Kowalski, Department of Immunology, Rheumatology and Allergy, Medical University of Lodz, Poland. (Marek.Kowalski@csk.am.lodz.pl); Štefan Krajcík, Geriatric department, Slovak Medical University, Bratislava, Slovakia. (skrajcik@szu.sk); Yesim Gökçe Kutsal, Director of Hacettepe University Research Center of Geriatric Sciences, Turkey. (ygkutsal@ gmail.com); Fulvio Lauretani, University Hospital of Parma, Parma, Italy. (flauretani@ ao.pr.it); Jūratė Macijauskiené, Department of Geriatrics, Medical Academy, Lithuanian University of Health Sciences; Kaunas, Lithuania. (jurate.macijauskiene@1smuni.lt); Marte Mellingsæter, Akershus University hospital, Norway. (cmelling@online.no); France Mourey, Inserm 1093 UFR santé université Bourgogne Franche-Comté, France. (france.mourey@u-bourgogne.fr); Fati Nourashemi, Gérontopôle de Toulouse, France. (nourhashemi.f@chu-toulouse.fr); Csaba Nyakas, Semmelweis University, Faculty of Health Sciences, Research Unite for Behavioral Physiology, Budapest, Hungary. (nyakas@ tf.hu); François Puisieux, Département de Gériatrie, CHU de Lille, France. (Francois. puisieux@chru-lille.fr); Patrick Rambourg, Pôle de pharmacie, CHU Montpellier, France. (p-rambourg@chu-montpellier.fr); Alfonso González Ramírez, Working Group of Osteoporosis, Falls and Fractures of the Spanish Geriatrics Society; Unit of Geriatrics Universitary Hospital of Salamanca, Spain. (alfonsogr@segg.es); Kilian Rapp, Department of Geriatrics and Geriatric Rehabilitation, Robert-Bosch-Hospital, Stuttgart, Germany (Kilian.Rapp@rbk.de); Yves Rolland, Gérontopôle de Toulouse, Institut du Vieillissement, Centre Hospitalo-Universitaire de Toulouse; Unité Mixe de Recherche, Institut National de la Santé et de la Recherche Médicale 1027, University of Toulouse III, Toulouse, France. (rolland.y@chu-toulouse.fr); Jesper Ryg, Department of Geriatric Medicine,
Odense University Hospital, Department of Clinical Research, University of Southern Denmark. (Jesper.Ryg@rsyd.dk); Opinder Sahota, Department of Orthogeriatric Medicine \& Consultant Physician, QMC, Nottingham University Hospitals NHS Trust, UK. (opinder. sahota@nuh.nhs.uk); Sanne Snoeijs, Department of care demand of the chronically ill and disabled International Comparative Health Services Research, Utrecht, The Netherlands. (s.snoeijs@nivel.nl); Yannick Stephan, EA 4556 Dynamic of Human Abilities and Health Behaviors, University of Montpellier, France. (yannick.stephan@univmontp1.fr); Eric Thomas, Departement de rhumatologie, Pole Os et articulations, Hopital Lapeyronie, Université de Montpellier, Montpellier, France. (e-thomas@chu-montpellier. fr); Chris Todd, School of Nursing, Midwifery and Social Work, University of Manchester, Manchester, UK. (Chris.Todd@manchester.ac.uk); Jonathan Treml, Co-Chair British Geriatrics Society Falls and Bone Health Section.Department of Geriatric Medicine, Queen Elizabeth Hospital, Birmingham UK. (Jonathan.Treml@uhb.nhs.uk).

** For the European Society for Clinical and Economic Aspects of Osteoporosis and Osteoarthritis (ESCEO), Osteoporosis Research and Information Group (GRIO), and International osteoporosis Foundation (IOF): Rick Adachi, St. Joseph's Hospital, Western University, London, Ontario, Canada;IOF. (jd.adachi@sympatico.ca); Donato Agnusdei, Skeletal Diseases, Eli Lilly and Co., Italy; IOF. (donato@lilly.com); Jean-Jacques Body, CHU Brugmann, Université Libre de Bruxelles, Brussels, Belgium; ESCEO/IOF. (jean-jacques.body@chu-brugmann.be); Olivier Bruyère, Department of Public Health, Epidemiology and Health Economics, University of Liège, Liège, Belgium; ESCEO/IOF. (olivier.bruyere@ulg.ac.be); Peter Burckardt, Hirslanden Bois Cerf, Lausanne, Switzerland; ESCEO/IOF. (pburckhardt@eva-basel.ch); Jorge B. Cannata-Andia, Bone and Mineral Research Unit, Hospital Universitario Central de Asturias, Universidad de Oviedo Oviedo , Spain; ESCEO/IOF. (cannata@hca.es); John Carey, Department of Rheumatology, Galway University Hospitals, Galway, Republic of Ireland National University of Ireland Galway, Galway, Republic of Ireland; ESCEO/IOF. (john.carey@hse.ie) Dinh-Chen Chan, Department of Gerontology and Geriatrics, National Taiwan University Hospital, Taipei, Taiwan; Department of Internal Medicine, National Taiwan; IOF. (dingchengchan@ntu. edu.tw); Thierry Chevalley, Division of Bone Diseases, University Hospitals and Faculty of Medicine, Geneva, Switzerland; ESCEO/IOF (thierry.chevalley@hcuge.ch) Martine Cohen-Solal, Inserm U1132 \& USPC Paris-Diderot, Department of rheumatology, Hôpital Lariboisière, France; GRIO. (martine.cohen-solal@inserm.fr); Bess Dawson-Hughes, Jean Mayer United States Department of Agriculture Human Nutrition Research Center on Aging at Tufts University, Boston, MA, USA; IOF. (bess.dawson-hughes@tufts. edu); Elaine M Dennison, NIHR Southampton Biomedical Research Centre, University of Southampton and University Hospital Southampton, Southampton, UK; ESCEO/IOF (emd@mrc.soton.ac.uk); Jean-Pierre Devogelaer, Department of Rheumatology, SaintLuc University Hospital, Université Catholique de Louvain, Brussels, Belgium; ESCEO/ IOF. (devogelaer@ruma.ucl.ac.be); Patrice Fardellone, Department of Rheumatology, Hôpital Nord,; INSERM U1088, Amiens, France; GRIO. (fardellone.patrice@chu-amiens. fr); Jean-Marc Féron (Department of Orthopaedic and Trauma Surgery. Saint Antoine Hospital. UPMC-Sorbonne Universités. Paris, France; GRIO. (jean-marc.feron@aphp.fr); Adolfo Diez Perez, Department of Internal Medicine, Hospital del Mar, Director of the Bone and Joint Research Unit at the Municipal Institute of Medical Research, Barcelona, Spain, ESCEO/IOF. (adiez@imas.imim.es); Dieter Felsenberg, Centre for Muscle and Bone Research, Charité Universitätsmedizin Berlin, Hindenburgdamm 30, 12203, Berlin, Germany; ESCEO/IOF. (dieter.felsenberg@ @ charite.de); Claus Glueer, Universitatsklinikum Schleswig-Holstein ,Kiel, Germany; ESCEO/IOF (glueer@rad.uni-kiel.de); Nocholas Harvey, MRC Lifecourse Epidemiology Unit, University of Southampton, Southampton, SO16 6YD, UK; ESCEO/IOF. (nch@mrc.soton.ac.uk); Mickael Hiligsman, Department of Health Services Research, School for Public Health and Primary Care (CAPHRI), Maastricht University,, The Netherlands; ESCEO/IOF. (m.hiligsmann@ maastrichtuniversity.nl); Muhammad Kassim Javaid, NIHR Musculoskeletal Biomedical Research Unit, Nuffield Department of Orthopaedics, University of Oxford, Oxford, UK, ESCEO/IOF. (kassim.javaid@ndorms.ox.ac.uk); Niklas Rye Jörgensen, Research Center for Ageing and Osteoporosis, Department of Clinical Biochemistry, Copenhagen University Hospital, Rigshospitalet, Glostrup, Denmark; Institute of Clinical Medicine, Faculty of Health Sciences, University of Copenhagen, Denmark, ESCEO/IOF (niklas@ dadlnet.dk); David Kendler, University of British Columbia, Vancouver, Canada; IOF. (davidkendler@gmail.com); Marius Kraenzlin, University Hospital Basel, Petersgraben, Basel, Switzerland; ESCEO/IOF. (marius.kraenzlin@unibas.ch); William D Leslie, College of Medicine, University of Manitoba, Winnipeg, Manitoba, Canada; IOF. (bleslie@sbgh. mb.ca); E. Michael Lewiecki, New Mexico Clinical Research \& Osteoporosis Center Albuquerque, NM, USA; IOF. (mlewiecki@gmail.com); Toshitaka Nakamura, National Center for Global Health and Medicine, Tokyo 162-8655, Japan; IOF (t-nak@utopia. ocn.ne.jp) Alexandra Papaioannou, Department of Medicine, McMaster University , Hamilton, ON , Canada; IOF. (papaioannou@hhsc.ca); Christian Roux, Department of Rheumatology, Cochin Hospital, and Epidemiology and Biostatistics Unit, Sorbonne Paris Cité Research Center, Paris Descartes University, INSERM U1153, Paris, France; ESCEO/ GRIO/IOF. (christian.roux@ aphp.fr); Stuart Silverman, Cedars-Sinai Medical Center, 8700 Beverly Boulevard, Los Angeles, CA 90048, USA, IOF. (stuarts@bhillsra.com); Manuel Sosa Henriquez Research Group into Osteoporosis and Mineral Metabolism, University of Las Palmas de Gran Canaria, Spain; Bone Metabolism Unit, Internal Medicine Service, University Insular Hospital, Las Palmas de Gran Canaria, Spain; ESCEO/IOF. (msosa@ono.com); Thierry Thomas hôpital de Bellevue, Saint-Etienne, France; Groupe de Recherche et d'Information sur les Osteoporoses, ESCEO/GRIO//IOF. (thierry.thomas@ 


\section{JNHA: GERIATRIC SCIENCE}

chu-st-etienne.fr); Samual Vasikaran School of Pathology and Laboratory Medicine, University of Western Australia, Nedlands, WA, 6009, Australia; IOF. (samuel.vasikaran@ health.wa.gov.au); Nelson B. Watts, Mercy Health Osteoporosis and Bone Health Services Clinical Trial Center.), Cincinnati, Ohio, USA; IOF. (nelson.watts@uc.edu); Georges Weryha, CHU de Nancy, service d'endocrinologie, 54500 Vandœuvre-lès-Nancy, France ; GRIO. (g.weryha@chu-nancy.fr); Valérie Bousson, Service de Radiologie Ostéoarticulaire, Hôpital Lariboisière, Paris, France; GRIO. (valerie.bousson@aphp.fr); Véronique Breuil, Nice University Hospital, Pasteur 2 Hospital, Department of Rheumatology; UMR E-4320 TIRO-MATOs CEA/iBEB, Nice Sophia Antipolis University, France; GRIO (breuil.v@ chu-nice.fr); Laure Chapuis, Service de rhumatologie, 35500 Vitré, France; GRIO. (laure.chapuis@wanadoo.fr); Michel Laroche, Centre de Rhumatologie, CHU Purpan, Toulouse; GRIO. (laroche.m@chu-toulouse.fr); Erick Legrand, Service de rhumatologie, CHU Angers, France ; GRIO. (ErLegrand@chu-angers.fr); Eric Lespessailles, Service de Rhumatologie - CHR Orléans - La Source, France; GRIO. (eric.lespessailles@ chr-orleans.fr); Jacques Morel, Département de rhumatologie, Pole Os et articulations, Hopital Lapeyronie Université Montpellier I, Montpellier, France; Société Française de Rhumatologie.(j-morel@chu-montpellier.fr)

\section{References}

1. Johnell O, Kanis JA. An estimate of the worldwide prevalence and disability associated with osteoporotic fractures. Osteoporos Int 2006;17:1726-33.

2. Fife D, Barancik JI. Northeastern Ohio Trauma Study III: incidence of fractures. Ann Emerg Med 1985;14:244-8.

3. Cummings SR, Nevitt MC. Non-skeletal determinants of fractures: the potential importance of the mechanics of falls. Study of Osteoporotic Fractures Research Group. Osteoporos Int 1994;4 Suppl 1:67-70

4. Burge R, Dawson-Hughes B, Solomon DH, Wong JB, King A, Tosteson A. Incidence and economic burden of osteoporosis-related fractures in the United States, 20052025. J Bone Miner Res 2007;22:465-75.

5. Bliuc D, Nguyen ND, Milch VE, Nguyen TV, Eisman JA, Center JR. Mortality risk associated with low-trauma osteoporotic fracture and subsequent fracture in men and women. JAMA 2009;301:513-21.

6. Cooper C, Cole ZA, Holroyd CR, Earl SC, Harvey NC, Dennison EM, et al. Secular trends in the incidence of hip and other osteoporotic fractures. IOF CSA Working Group on Fracture Epidemiology. Osteoporos Int 2011;22:1277-88.

7. Roux C, Wyman A, Hooven FH, Gehlbach SH, Adachi JD, Chapurlat RD, GLOW investigators et al. Burden of nonhip, non-vertebral fractures on quality of life in postmenopausal women: the Global Longitudinal study of Osteoporosis in Women (GLOW). Osteoporos Int 2012;23:2863-71.

8. Bischoff-Ferrari H. Fragility fractures: the future epidemic and its challenges. Skeletal Radiol. 2013;42:161-3.

9. Blain H, Abecassis F, Adnet PA, Alomène B, Amoyal M, Bardy B, et al. Living Lab Falls-MACVIA-LR: The falls prevention initiative of the European Innovation Partnership on Active and Healthy Ageing (EIP on AHA) in Languedoc-Roussillon. Eur Geriatr Med 2014;5:416-25.

10. European Innovation Partnership on Active and Healthy Ageing. ACTION PLAN A2 on Specific Action on innovation in support of 'Personalized health management, starting with a Falls Prevention Initiative' Update January 2013 https://ec.europa.eu/ research/innovation-union/pdf/active-healthy-ageing/a2_action_plan.pdf

11. Hung WW, Egol KA, Zuckerman JD, Siu AL. Hip fracture management: tailoring care for the older patient. JAMA 2012;307:2185-94.

12. Bischoff-Ferrari HA, Meyer O. Comparative effectiveness of pharmacologic treatments to prevent fractures: is this all we need to know? Ann Intern Med 2014;161:755-6.

13. Järvinen TL, Michaëlsson K, Jokihaara J, Collins GS, Perry TL, Mintzes B, et al. Overdiagnosis of bone fragility in the quest to prevent hip fracture. BMJ 2015;350:h2088.

14. Compston J. Overdiagnosis of osteoporosis: fact or fallacy? Osteoporos Int 2015;26:2051-4.

15. O'Loughlin JL, Robitaille Y, Boivin JF, Suissa S. Incidence of and risk factors for falls and injurious falls among the community-dwelling elderly. Am J Epidemiol 1993; 137:342-54.

16. Tinetti ME. Clinical practice. Preventing falls in elderly persons. N Engl J Med 2003;348:42-9.

17. Tinetti ME, Speechley M, Ginter SF. Risk factors for falls among elderly persons living in the community. New England Journal of Medicine 1988;319:1701-7.

18. Campbell AJ, Borrie MJ, Spears GF, Jackson SL, Brown JS, Fitzgerald JL. Circumstances and consequences of falls experienced by a community population 70 years and over during a prospective study. Age and Ageing 1990;19: 136-41.

19. Milat AJ, Watson WL, Monger C, Barr M, Giffin M, Reid M. Prevalence, circumstances and consequences of falls among community-dwelling older people: results of the 2009 NSW Falls Prevention Baseline Survey. N S W Public Health Bull 2011;22:43-8

20. Cameron ID, Gillespie LD, Robertson MC, Murray GR, Hill KD, Cumming RG, Kerse N. Interventions for preventing falls in older people in care facilities and hospitals. Cochrane Database Syst Rev 2012;12:CD005465.
21. Gillespie LD, Robertson MC, Gillespie WJ, Sherrington C, Gates S, Clemson LM, Lamb SE. Interventions for preventing falls in older people living in the community. Cochrane Database Syst Rev 2012;9:CD007146.

22. STEADI algorithm CDC's Stopping Elderly Accidents, Deaths \& Injuries (STEADI) Algorithm providing tools and educational material for health care providers. Centers for Disease Control and Prevention, National Center for Injury Prevention and Control, Division of Unintentional Injury Prevention. Available from:stevens http:// www.cdc.gov/homeandrecreationalsafety/Falls/steadi/index.html.7

23. Stevens JA, Phelan EA. Development of STEADI: a fall prevention resource for health care providers. Health Promot Pract 2013;14:706-14.

24. El-Khoury F, Cassou B, Latouche A, Aegerter P, Charles MA, Dargent-Molina P. Effectiveness of two year balance training programme on prevention of fall induced injuries in at risk women aged 75-85 living in community: Ossébo randomised controlled trial. BMJ 2015;351:h3830.

25. Wagner H, Melhus H, Gedeborg R, Pedersen NL, Michaëlsson K. Simply ask them about their balance-future fracture risk in a nationwide cohort study of twins. Am J Epidemiol 2009;169:143-9.

26. Caillet P, Klemm S, Ducher M, Aussem A, Schott AM. Hip fracture in the elderly: a re-analysis of the EPIDOS study with causal Bayesian networks. PLoS One 2015; 10:e0120125.

27. Furrer R, van Schoor NM, de Haan A, Lips P, de Jongh RT. Gender-specific associations between physical functioning, bone quality, and fracture risk in older people. Calcif Tissue Int 2014;94:522-30.

28. Lundin H, Sääf M, Strender LE, Nyren S, Johansson SE, Salminen H. One-leg standing time and hip-fracture prediction. Osteoporos Int 2014;25:1305-11.

29. Lord SR, March LM, Cameron ID, Cumming RG, Schwarz J, Zochling J, Chen JS, Makaroff J, Sitoh YY, Lau TC, Brnabic A, Sambrook PN. Differing risk factors for falls in nursing home and intermediate-care residents who can and cannot stand unaided. J Am Geriatr Soc. 2003;51:1645-50.

30. El-Khoury F, Cassou B, Charles MA, Dargent-Molina P. The effect of fall prevention exercise programmes on fall induced injuries in community dwelling older adults: systematic review and meta-analysis of randomised controlled trials. BMJ 2013;347:f6234.

31. Stubbs B, Brefka S, Denkinger MD. What Works to Prevent Falls in CommunityDwelling Older Adults? Umbrella Review of Meta-analyses of Randomized Controlled Trials. Phys Ther 2015;95:1095-110.

32. Keall MD, Pierse N, Howden-Chapman P, Cunningham C, Cunningham M, Guria $\mathrm{J}$, Baker MG. Home modifications to reduce injuries from falls in the home injury prevention intervention (HIPI) study: a cluster-randomised controlled trial. Lancet 2015;385:231-8.

33. Li W, Procter-Gray E, Lipsitz LA, Leveille SG, Hackman H, Biondolillo M, Hannan MT. Utilitarian walking, neighborhood environment, and risk of outdoor falls among older adults. Am J Public Health. 2014;104:e30-7.

34. Campbell AJ, Robertson MC. Fall prevention: single or multiple interventions? Single interventions for fall prevention. J Am Geriatr Soc 2013;61:281-4.

35. Vlaeyen E, Coussement J, Leysens G, Van der Elst E, Delbaere K, Cambier D, et al. Center of Expertise for Fall and Fracture Prevention Flanders. Characteristics and effectiveness of fall prevention programs in nursing homes: a systematic review and meta-analysis of randomized controlled trials. J Am Geriatr Soc 2015;63:211-21.

36. Day LM. Fall prevention programs for community-dwelling older people should primarily target a multifactorial intervention rather than exercise as a single intervention. J Am Geriatr Soc 2013;61:284-5.

37. Ambrose AF, Cruz L, Paul G. Falls and Fractures: A systematic approach to screening and prevention. Maturitas 2015;82:85-93.

38. Zhang W, Zhu C, Sun M, Ge Y, Yan G. Efficacy of bisphosphonates against hip fracture in elderly patients with stroke and Parkinson diseases: meta-analysis of randomized controlled trials. J Stroke Cerebrovasc Dis 2014;23:2714-24.

39. Taylor BC, Schreiner PJ, Stone KL, Fink HA, Cummings SR, Nevitt MC, et al. Long-term prediction of incident hip fracture risk in elderly white women: study of osteoporotic fractures. J Am Geriatr Soc 2004;52:1479-86.

40. Kojima G. Frailty as a Predictor of Future Falls Among Community-Dwelling Older People: A Systematic Review and Meta-Analysis. J Am Med Dir Assoc 2015;S1525_ 8610:00439-9.

41. Beswick AD, Rees K, Dieppe P, Ayis S, Gooberman-Hill R, Horwood J, Ebrahim S Complex interventions to improve physical function and maintain independent living in elderly people: a systematic review and meta-analysis. Lancet 2008;371:725-35.

42. American Geriatrics Society/British geriatrics Society clinical practice guideline:prevention of falls in older persons (2010). New York, NY: American Geriatrics Society, 2011. Available from http://www.americangeriatrics.org/health care professionals/clinical practice/clinical guidelines recommendations/2010.

43. Rizzoli R, Bianchi ML, Garabédian M, McKay HA, Moreno LA. Maximizing bone mineral mass gain during growth for the prevention of fractures in the adolescents and the elderly. Bone 2010;46:294-305.

44. Specker B, Minett M. Can physical activity improve peak bone mass? Curr Osteoporos Rep 2013;11:229-36.

45. Golden NH, Abrams SA; Committee on Nutrition. Optimizing bone health in children and adolescents. Pediatrics 2014;134:e1229-43.

46. Harvey N, Dennison E, Cooper C. Osteoporosis: a lifecourse approach. J Bone Miner 


\section{A COMPREHENSIVE FRACTURE PREVENTION STRATEGY IN OLDER ADULTS}

Res 2014;29:1917-25.

47. Milte R, Crotty M. Musculoskeletal health, frailty and functional decline. Best Pract Res Clin Rheumatol 2014;28:395-410.

48. Kanis JA, McCloskey EV, Johansson H, Cooper C, Rizzoli R, Reginster JY; Scientific Advisory Board of the European Society for Clinical and Economic Aspects of Osteoporosis and Osteoarthritis (ESCEO) and the Committee of Scientific Advisors of the International Osteoporosis Foundation (IOF). European guidance for the diagnosis and management of osteoporosis in postmenopausal women. Osteoporos Int 2013;24:23-57.

49. Kanis JA, Rizzoli R, Cooper C, Reginster JY. Challenges for the development of bone-forming agents in Europe. Calcif Tissue Int 2014;94:469-73.

50. Kanis JA, McCloskey E, Branco J, Brandi ML, Dennison E, Devogelaer JP, Ferrari S, Kaufman JM, Papapoulos S, Reginster JY, Rizzoli R. Goal-directed treatment of osteoporosis in Europe. Osteoporos Int 2014;25:2533-43.

51. Rizzoli R, Branco J, Brandi ML, Boonen S, Bruyère O, Cacoub P, Cooper C, DiezPerez A, Duder J, Fielding RA, Harvey NC, Hiligsmann M, Kanis JA, Petermans J, Ringe JD, Tsouderos Y, Weinman J, Reginster JY. Management of osteoporosis of the oldest old. Osteoporos Int 2014;25:2507-29.

52. Kanis JA, Melton LJ 3rd, Christiansen C, Johnston CC, Khaltaev N. The diagnosis of osteoporosis. J Bone Miner Res 1994;9:1137-41.

53. Assessment of fracture risk and its application to screening for postmenopausal osteoporosis. Report of a WHO Study Group. Geneva, World Health Organization, 1994 (WHO Technical Report Series, No. 843)

54. International Society for Clinical Densitometry. 2013 Official Positions - Adult. http://www.iscd.org/ official-positions/2013-iscd-official-positions-adult/.

55. Masud T, Langley S, Wiltshire P, Doyle DV, Spector TD. Effect of spinal osteophytosis on bone mineral density measurements in vertebral osteoporosis. BMJ 1993;307:172-3.

56. Kanis JA, McCloskey EV, Johansson H, Oden A, Melton LJ 3rd, Khaltaev N.A reference standard for the description of osteoporosis. Bone. 2008;42:467-75.

57. Kanis JA, Hans D, Cooper C, Baim S, Bilezikian JP, Binkley N, et al, and the Task Force of the FRAX Initiative. Interpretation and use of FRAX in clinical practice. Osteoporos Int 2011;22: 395-411.

58. Blain H, Rolland Y, Beauchet O, Annweiler C, Benhamou CL, Benetos A, et al; Groupe de recherche et d'information sur les ostéoporoses et la Société française de gérontologie et gériatrie. Usefulness of bone density measurement in fallers. Joint Bone Spine 2014;81:403-8.

59. Nevitt MC, Cummings SR. Type of fall and risk of hip and wrist fractures: The study of osteoporotic fractures. J Am Geriatr Soc 1993;41:1226-34.

60. Schuit SC, van der Klift M, Weel AE, de Laet CE, Burger H, Seeman E, Hofman A, et al. Fracture incidence and association with bone mineral density in elderly men and women: the Rotterdam Study. Bone 2004;34:195-202

61. Crandall CJ, Newberry SJ, Diamant A, Lim YW, Gellad WF, Booth MJ, et al. Comparative effectiveness of pharmacologic treatments to prevent fractures: an updated systematic review. Ann Intern Med 2014;161:711-23.

62. Lyles KW, Colón-Emeric CS, Magaziner JS, Adachi JD, Pieper CF, Mautalen C, for the HORIZON Recurrent Fracture Trial et al. Zoledronic acid in reducing clinical fracture and mortality after hip fracture. N Engl J Med 2007;357:nihpa40967

63. Eriksen EF, Díez-Pérez A, Boonen S. Update on long-term treatment with bisphosphonates for postmenopausal osteoporosis: a systematic review. Bone 2014;58:126-35.

64. Hiligsmann M, Evers SM, Ben Sedrine W, Kanis JA, Ramaekers B, Reginster
JY, Silverman S, Wyers CE, Boonen A. A systematic review of cost effectiveness analyses of drugs for postmenopausal osteoporosis. Pharmacoeconomics 2015;33:205-24.

65. Boonen S, Black DM, Colón-Emeric CS, Eastell R, Magaziner JS, Eriksen EF et al. Efficacy and safety of a once-yearly intravenous zoledronic acid $5 \mathrm{mg}$ for fracture prevention in elderly postmenopausal women with osteoporosis aged 75 and older. J Am Geriatr Soc 2010;58:292-9.

66. Boonen S, McClung MR, Eastell R, El-Hajj Fuleihan G, Barton IP, Delmas P. Safety and efficacy of risedronate in reducing fracture risk in osteoporotic women aged 80 and older: implications for the use of antiresorptive agents in the old and oldest old. J Am Geriatr Soc 2004;52:1832-9.

67. Boonen S, Marin F, Mellstrom D, Xie L, Desaiah D, Krege JH, Rosen CJ. Safety and efficacy of teriparatide in elderly women with established osteoporosis: bone anabolic therapy from a geriatric perspective. J Am Geriatr Soc 2006;54:782-9.

68. Hochberg MC, Thompson DE, Black DM, Quandt SA, Cauley J, Geusens P, FIT Research Group et al. Effect of alendronate on the age-specific incidence of symptomatic osteoporotic fractures. J Bone Miner Res 2005;20:971-6.

69. Eastell R, Black DM, Boonen S, Adami S, Felsenberg D, Lippuner K, HORIZON Pivotal Fracture Trial et al. Effect of once yearly zoledronic acid five milligrams on fracture risk and change in femoral neck bone mineral density. J Clin Endocrinol Metab 2009;94:3215-25.

70. Reginster JY, Seeman E, De Vernejoul MC, Adami S, Compston J, Phenekos C, et al. Strontium ranelate reduces the risk of nonvertebral fractures in postmenopausal women with osteoporosis: Treatment of Peripheral Osteoporosis (TROPOS) study. J Clin Endocrinol Metab 2005;90:2816-22.

71. Boonen S, Adachi JD, Man Z, Cummings SR, Lippuner K, Törring O, et al Treatment with denosumab reduces the incidence of new vertebral and hip fractures in postmenopausal women at high risk. J Clin Endocrinol Metab 2011;96:1727-36

72. Rolland Y, Abellan Van Kan G, Gillette-Guyonnet S, Roux C, Boonen S, Vellas B. Strontium ranelate and risk of vertebral fractures in frail osteoporotic women. Bone 2011;48:332-8.

73. Greenspan SL, Perera S, Ferchak MA, Nace DA, Resnick NM. Efficacy and safety of single-dose zoledronic acid for osteoporosis in frail elderly women: a randomized clinical trial. JAMA Intern Med 2015;175:913-21.

74. Clinician's guide to prevention and treatment of osteoporosis; National Osteoporosis Foundation 2014.http://nof.org/files/nof/public/content/file/2791/upload/919.pdf

75. Javaid MK, Kyer C, Mitchell PJ, Chana J, Moss C, Edwards MH et al; IOF Fracture Working Group; EXCO. Effective secondary fracture prevention: implementation of a global benchmarking of clinical quality using the IOF Capture the Fracture $($ Best Practice Framework tool. Osteoporos Int 2015;26:2573-8.

76. Solomon DH, Patrick AR, Schousboe J, Losina E. The potential economic benefits of improved post-fracture care: a costeffectiveness analysis of a fracture liaison service in the US health-care system. J Bone Miner Res 2014;29:1667-747.

77. Yong JH, Masucci L, Hoch JS, Sujic R, Beaton D. Cost-effectiveness of a fracture liaison service-a real-world evaluation after 6 years of service provision. Osteoporos Int 2016;27:231-40.

78. Majumdar SR, Kim N, Colman I, Chahal AM, Raymond G, Jen H, et al. Incidental vertebral fractures discovered with chest radiography in the emergency department: prevalence, recognition, and osteoporosis management in a cohort of elderly patients. Arch Intern Med 2005;165:905-9. 